HOW

Volume 28, Number 3, pages 5 - 17

https://doi.org/10.19183/how.28.3.681

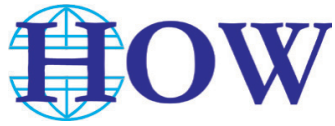

\title{
Colombian ELT Community and Scholarship: Current Pathways and Potency
}

\author{
La Comunidad y el Conocimiento Colombiano en la Enseñanza \\ del Inglés: Sus Caminos y Potencia Actual
}

\author{
Edgar Lucero ${ }^{1}$ \\ Adriana Castañeda-Londoño ${ }^{2}$
}

\begin{abstract}
This editorial article reflects on the paradigmatic changes that the Colombian ELT community has recently experienced due to the developments of local scholarship in varied topics. This editorial article makes the changes evident by introducing the papers for this special issue of HOW journal on its 25 years of numbered issues using the Open Journal Systems software. These include topics as interculturality, literacy, English language pre-service teacher construction and professional development, critical views about bilingual education policy, and the interrelation between gender and ELT. The local scholarship development in these topics displays a rupture with the ELT canon. By so doing, the Colombian ELT scholarship shows a potency that wields foundations for the ELT field in the country.
\end{abstract}

Keywords: Colombian ELT, ELT field, ELT scholarship, ELT knowledge, ELT foundations

\section{Resumen}

Este artículo editorial reflexiona sobre los cambios paradigmáticos que la comunidad colombiana del ELT ha experimentado recientemente debido a los desarrollos que el conocimiento local respectivo

He is a full-time teacher educator for Universidad de La Salle, Colombia. He is a Ph.D. candidate in Education at Universidad Distrital Francisco José de Caldas, Colombia. He holds an M.A. in Applied Linguistics and is specialized in English language Teaching Didactics. His research interests are in classroom interaction and pedagogical practicum.

elucero@unisalle.edu.co

ORCID ID: https://orcid.org/0000-0003-2208-5124

2 She holds a Ph.D. in Education from Universidad Distrital Francisco José de Caldas. She has worked as an English teacher for around fifteen years and has also been a teacher educator. She is interested in studying social aspects of language learning and teaching.

a.castanedal@correo.udistrital.edu.co

ORCID ID: https://orcid.org/0000-0001-8360-4528

This article is licensed under a Creative Commons Attribution-Non-Commercial-No-Derivatives 4.0 International License. License Deed can be consulted at https://creativecommons.org/licenses/by-nc-nd/4.0. 
ha tenido en varios temas. Este artículo editorial hace evidente estos cambios al introducir los artículos que hacen parte del número especial de la revista HOW en sus 25 años de publicar números con el software Open Journal Systems. Estos incluyen temas como la interculturalidad, la literacidad, la construcción y el desarrollo profesional de los docentes en formación, las visiones críticas acerca de la política de educación bilingüe y la interrelación entre género y el ELT. De todo esto, el desarrollo del conocimiento local sobre el ELT muestra su potencia que a su vez ensambla las bases para el ELT en el país.

Palabras clave: ELT colombiano, ELT, conocimiento, bases

\section{Introduction}

HOW began as a newsletter publishing short articles since the creation of the Colombian Association of Teachers of English (Asocopi) in 1966. By 1979, HOW had already edited 39 small publications. Since that year, a higher number of academic articles were included in each issue. In 1986, publishing HOW as a newsletter stopped for 10 years. The issuing of HOW resumed in 1996, the year when Mr. Luis Fernando Gómez, as the chief editor, issued HOW's number 1 of volume 1. During the next ten years, the editorial team of HOW consolidated it as a journal by following the parameters issued by Colciencias and the current trends of international periodicals ${ }^{3}$. This special issue celebrates 25 years of HOW as a journal publishing issued numbers to maintain "communication among English language teachers both in Colombia and abroad by offering opportunities for the dissemination of knowledge resulting from educational and research practices that concern English language teaching-learning issues." ${ }^{4}$

After more than half a century, English language teachers, educators, and researchers belonging to the Colombian ELT community have created a great variety of knowledge in and from their contexts. The more this knowledge creation happens, the more we, as an ELT community, become conscious about the need to communicate how ELT education occurs around the country. The permanent actions in which this creation occurs reveal a prominent production of local scholarship about ELT in Colombia. Part of it searches for conceptualizing the ELT field, another for struggle and resistance to imposed and hegemonic discourses and practices in the field, and another for change by considering peripheral perspectives or knowledge 'otherwise'. The truth is that the local ELT community might feel tension when abstracting the ELT field from the traditional standings. This is what we perceive in Asocopi and HOW; possibly, other Colombian journals in the field have also seen this. The ELT community has found that knowledge from elsewhere has influenced us since it extendedly holds decontextualized and unsuitable frames.

We would like to thank Jesús Alirio Bastidas, Ph.D., and Melba Libia Cárdenas, Ph.D., for this historical account of the journal. To know about the challenges that ASOCOPI and HOW have lived together, we suggest reading Cárdenas (2016), Meadows (2016), Lucero and Díaz (2016), and Bastidas (2017).

4 This is the purpose of HOW journal (https://howjournalcolombia.org/index.php/how) 
Thus, a need to think of Colombian ELT from our geopolitical locations has gained terrain. In the multiple topics in which this is evident, visions of emancipation are tangible. The articles in this current issue are evidence of this fact. They are local creations that display a look at other frontiers that surpass foreign and established frames about how to teach English and what to consider while doing it. On the whole, they constitute an assemblage of how Colombian ELT occurs from the authors' conceptualizations, which in turn present casts of a rupture with the established ELT canon.

There is consequently a search for more situated epistemologies, for other complementary paths that can give additional opportunities of constructing the Colombian ELT scholarship. It is our view that this reality is potent; there will then be more possibilities for our community to be completely viable. The production and constitution of the Colombian ELT scholarship should maintain a constant connection with the variety of our contexts. With this editorial article, and with this special issue of HOW in its 25 years of numbered issues using the Open Journal Systems software, we would like to invite the Colombian ELT community to continue searching for those possibilities of being and for those alternatives to strengthen local scholarship.

\section{Reflecting upon Paradigmatic Changes in Colombian ELT Development}

We, English language teachers and educators, do research and communicate it in a language that we learned and which now allows us to create thoughts, dwell in local stories, and create knowledge in situated realities. The social, political, epistemic, and geographical locations of our teachers' selves are involved in the act of creating knowledge. These different locations should entail the emergence of new categories of thought. Martinez Boom (2004) develops the concept of 'geo-pedagogy' to refer to the different shapes taken by schools, teachers, and pedagogy in particular areas of Colombia as defined by cultural or land borders. Therefore, a geo-pedagogy for ELT invites us to think of situated realities and practices.

The awareness of the need for a geo-localization of knowledge creation was not produced in a vacuum. Our first fountains of theoretical knowledge could have been ELT authors and practices coming from the Global North. Yet, many of us would not be able to continue giving meaning to our local realities exclusively with categories from elsewhere; in fact, we have gradually become more conscious about our place in the world and the need to raise our voices when it comes to understanding and defining what it means to teach and learn in the multi-faceted Colombian contexts.

Such 'in-between' epistemic (theoretical), physical (geographical), and emotional locations amid two worlds --the South and the North-- possibly entail the need to develop 
'border thinking'. In other words, these realities in which we are locally --and globally-embedded most likely push us to develop what Mignolo (2013) calls 'border thinking'. Border thinking is about 'thinking otherwise', 'thinking alternatively', or 'thinking from outside' of the existing theoretical perspectives available by distancing ourselves from taken-for-granted perspectives of, in our case, the ELT field (for probing more deeply into the concept of border thinking see also Anzaldúa, 1987).

The concept of border thinking may help us become aware that as English language teachers, educators, or researchers, we are intercultural translators of two worlds that are simultaneously in struggle and symbiosis. In other words, the Global North is loosely understood as a set of world views (i.e., hegemonic and transnational ideas on how to run the world's economy, education, politics, subjectivities, and much more) that stem from North America and Western Europe. It has impacted the Global South (i.e., developing countries which receive the --mostly negative-- effect of said hegemonic ideas developed in the North) in ways that cause more harm than good. Education --particularly ELT-- is no exception to this phenomenon.

As a matter of fact, some of the Global-North traits incorporated into the Global-South ELT practices can be observable in at least three areas, as described by Saavedra \& SalazarPérez (2018); these are, (a) the over-emphasis allocated to testing and its results in students' subjectivities and social mobility; (b) the fine-grained and poorly contested discourse of language-as-a-resource that pervades most language programs; and (c) the burden placed upon teachers and learners for the lack of success at learning English within educational systems that are undoubtedly unfair, inequitable, racist, and classist.

In such a state of affairs, English language teachers, educators, or researchers who may feel geopolitically located in the Global South or those who have a view of social justice in ELT might not feel comfortable conceptualizing the ELT field in said terms. So, how have ELT teachers, educators, and researchers started to delink or detach from Global North epistemological traits? To answer this question, there is a need to take a look at the broader sociological and educational Colombian context. Some attempts to develop border thinking in Colombia can be found as early as the 1970s of the past century with --but not exclusively-- sociologist Fals Borda who wrote that knowledge is unfinished, subject to be reasoned through dialogue, and prompt to have a social, economic, and political impact. Therefore, a vision of social responsibility with the particularities of each context should guide the production of knowledge. He contended that:

Neither the frames of reference nor the existing categories in the normal sociological paradigms that had been received from Europe and the United States were satisfactory. We found many of those frames inapplicable to the existing realities, ideologically biased to defend the dominant 
bourgeois elite, and extremely specialized or compartmentalized to understand the global meaning of the phenomena we found daily. (Fals Borda, 2009, p. 257) [Own translation]

In a similar vein, reflecting upon the emergence of situated knowledge, Mejia Jiménez (2011) points out that the pedagogical knowledge created in Latin America is multiple yet scattered. For him, the intent to have local production of knowledge can be traced back to the formation of the republics. For example, in the 50s and 60s of the past century, he says, there were multiple intentions to develop our own ways of thinking. Despite being heavily attached to Euro-American worldviews, some borders were being delimited to configure a thought of our own.

Mejia Jiménez (2011) explains that despite the subordinated relationship with the EuroAmerican world in terms of politics, economics, or intellectual production, some Latin American authors recognized that such subordination was hindering the development of our own ways of thinking/feeling and experiencing the world. Even so, we must recognize that many ideas of emancipation also came via the critical thought of those geographical regions. Still, at the heart of such reflections, the idea that there was a need to think of Latin America from our own geopolitical locations has been more and more prevalent consciously or unconsciously, either by political decision or by the impossibility to fully apply theoretical or methodological principles alien to the Latin American contexts.

The fact that there was much debate going on in the social sciences in more general terms could have possibly permeated several visions of emancipation in a number of educational areas, and particularly in some conceptualizations of the ELT field. Although an overt reflection on delinking from mainstream ELT thought cannot be taken as a general trend in the Colombian ELT, we can be assured that there has been a gradual increase in the local production of knowledges as observed in the thought-provoking ideas that this issue brings.

\section{Walking the Trails of Local Knowledge}

The articles in this current issue are presented as foundations that escape from the supposed rationality of what needs to be done, and how, in Colombian ELT. These foundations to a great extent move away from foreign and established grand narratives about how to teach English and what to consider while doing it. Altogether, the articles offer bases that embody several positions on varied topics. For example, Bertha Ramos, by providing a comprehensive view of what interculturality means, and how it has contributed to current and future trends in the field of ELT and teacher education in Colombia, clamors for situated views of intercultural practices as possibilities to understand and explore interculturality in the Colombian ELT. In a similar line of thought, Carlos Rico Troncoso avows what foreign language teaching should be, and how we as an ELT community should be thinking about 
culture and interculturality in our classrooms. His invitation is to think about the need to interculturalize foreign language teaching in our contexts.

Other positions come from sustained work on the topic of literacies in Colombia. For example, Ana Clara Sánchez Olarte highlights the complexity of Colombian education, the dynamic nature of contexts and meanings in it, and the examination of the role of those contexts in the English language teaching and learning processes in the country. Additionally, Amparo Clavijo Olarte, by sharing her beliefs about language and literacy practices, clamors for an understanding of literacy as a social practice that evolves as critical literacies to develop knowledge through community pedagogies and city semiotic landscapes. In a similar fashion, Raúl Alberto Mora shares how critical theories have informed his main research areas and work on literacy. Through a series of epiphanies manifested during his journey as a researcher and scholar-activist, he discusses his main scholarly influences with the literature, mentors, and colleagues in this field. Frank Giraldo offers a view of the assessment of literacy practices in the Colombian ELT. In his paper, he discusses ongoing issues about language assessment literacy that have emerged in his research works. He offers suggestions for fostering them among pre- and in-service teachers of English in the country. He argues for a collective raising of the status and nature of language assessment and its impact on teachers' professional development in the country.

The room is also open for positions referring to English language pre-service teachers' education. The way they are constructed as English language teachers during pedagogical practicum is the interest of Jairo Castañeda Trujillo. In his paper, he focuses on their experiences that he has collected during his research works with them; the experiences that enact the construction of their teacher selves become his raising voice in Colombian ELT. As important as the construction of pre-service teachers as English language teachers is, it is the professional development that they, and in-service teachers, can receive. Adriana Gonzalez Moncada considers the professional development of English teachers in Colombia by showing in her paper how the discourses and decisions about teachers' continuing learning represent their views of language and second language acquisition, teaching, and learning. She highlights the power of these concepts over the major decisions made at the local and school levels from the discourses that have shaped English teachers' professional development in Colombia's National Program of Bilingualism. For her, there is a necessity of maintaining critical scholarly work to contribute to the construction of local knowledge for future reflection in Colombian ELT. Correspondingly, by following a critical view of the bilingual education policy in Colombia, Carmen Helena Guerrero and Álvaro Quintero Polo offer their contributions to the ELT field in Colombia by discussing the dimensions of language policies and the teachers' relevant agency to the study of these policies in the country.

Other relevant topics are also part of this special issue. For instance, Harold CastañedaPeña presents in his article a systematization of reference frameworks for the study of the 
particular interrelation between gender and ELT. From a historical perspective, he constructs a reflection on the collective achievements in this field of study in Colombia. He argues for a reflection on potential actions at the research and pedagogical levels in the interrelation between gender and ELT. Additionally, Melba Libia Cárdenas analyzes the role played by locally edited journals in the decolonialization of knowledge. She identifies the contributions, suggestions, and challenges for publications in the English Language Teaching area. She does it based on her studies on academic writing and the publication of scientific journals in the ELT field. She encourages greater participation by the ELT community in the dissemination of their work in order to value knowledge generated in peripheral contexts, without ignoring links with the global world.

\section{Coming to Grips with Colombian ELT Thought}

Local construction of scholarship in the Colombian ELT, apart from the contents of the above-mentioned articles in this current issue, also occurs in the vast production presented in other national journals. To mention just a few, the Colombian ELT community recognizes HOW, Profile, GiST, Colombian Applied Linguistics Journal, Eletawa, and Íkala, among others from varied universities in the country, as sources that portray different ways of thinking about the ELT in the country. The topics are varied: developing language and communication skills in varied contexts and levels, teaching English to learners with diverse characteristics, reflecting on teachers' and students' educational practices, displaying results of implementing various teaching and assessment approaches or methodologies, and analyzing tendencies and beliefs in English language education, among other topics. There is usually an article for a topic a researcher can imagine in the field of ELT in Colombia. This richness of topics provides a dialogue among local authors that is also evident in their publications in other external journals. This multiverse of knowledges ${ }^{5}$ (Qin, 2018), in our opinion, makes visible the Colombian ELT, in and out of the country, without constituting its authors' thinking as attaining formulas or procedures to follow but as valuable foundations that enter the global field of ELT. In agreement with Mignolo and Walsh (2018), (ELT) teachers are not containers, nor replicators of knowledge but producers of it.

Altogether, these authors have to some extent developed an assemblage of associated foundations of how Colombian ELT may occur and be constituted. Their works give meaning to their practices in specific contextual circumstances, in several cases, by abandoning, initially, a technical or instrumental vision of language and language education. Thus, they have ended up problematizing the canon of ELT knowledge and practices (as indicated by Castañeda-Peña, 2018; Castañeda-Londoño, 2018) to debate them for the search of more

Qin (2018) talks about a multiverse of knowledge (in singular). We pluralize knowledge since it is our belief that knowledge is heterogeneous, of different types and dimensions, and context-situated (see Castañeda-Londoño, 2018, 2021). 
situated epistemologies that allow the emergence of grounds of knowledges and experiences in our contexts.

In the articles included in this current issue, we then perceive a delinking, a rupture with that canon of ELT knowledge and practices. The Colombian authors of these articles, as well as many others that have expressed this rupture, seem to clamor for resistance and dismantlement of the idea that canon tells the unique truths of how to think and do ELT around the world. By thorough observation, analysis, reasoning, and research on what happens in the diversity of contexts of ELT in Colombia, local authors have perceived different ways in which the canon of ELT knowledge and practices can be decontextualized and incongruous while maintaining a dominant status. As Clavijo-Olarte (this issue) deeply thinks from her experiences, "theory informs, but the practice has the power to transform" (p. 49).

That transformation can occur in other complementary ways with the reflection on experiences while teaching the English language or doing research on it. For instance, the possibility that the Colombian ELT community has to get access to literature and combined digital resources about topics of interest in the ELT field, locally and globally, provides chances of constructing scholarship; so is it when the Colombian ELT community can get into professional development and postgraduate studies that allow analyzing, reflecting on, re-thinking, and transforming processes and practices in language education. These changes improve if they are experienced in company with members of the ELT community. The opportunities to share and create knowledge increase noticeably when efforts are made collectively. Through collaborative work, not only can working and researching with colleagues be more significant and fruitful but also writing and sharing about research studies on common topics of interest can be more satisfactory and grow.

We perceived that all these traits are evident in the papers that the invited authors have written for this special issue of HOW on its 25 years of numbered issues using the Open Journal Systems software. We are sure that these traits have also been shared by many in the Colombian ELT community. Certainly, plenty of others can emerge. Our invitation is to continue searching for opportunities to make, in this case, Colombian scholarship about ELT more foundational, situated, varied, dynamic, transformative, and transcendental. Let the Colombian ELT scholarship walk with the help of its community.

\section{The Potency of the Colombian ELT Scholarship}

The articles published in this special issue of HOW journal, plus the numerous articles published thus far by Colombian authors in the multiple and well-known journals at home and overseas, show how potent local scholarship about ELT is. This scholarship looks at the 
diversity of events, situations, experiences, and knowledges that happen in the Colombian contexts of ELT. Thus, local scholarship is alive; it is active with plentiful chances of continued existence.

As presented in the previous subtitle, the diversity of topics about which Colombian authors have written eventually creates a foundation in the ELT field of the country. Each article forms the scaffolding for the construction of more scholarship since each is sustained and opens tracks to keep studying what happens in the Colombian field of ELT. As a local ELT community, we are still in debt to peruse more closely at the potency of Colombian ELT scholarship which, combined with a stronger feeling of ownership, can then create more possibilities of being in the extended global field of ELT.

As part of the Colombian ELT community, we should keep burning the flame of constructed scholarship; in this way, the possibilities of being (existence) for this community are more palpable. If we raise the voices of local teachers, educators, researchers, and studentteachers, more opportunities to find out what happens in our contexts are possible. If more contextualized studies are known, more chances to transform our teaching and learning actions of the English language can emerge. If we continue revealing more findings and insights of those studies, more chances for building our continuity of thinking and doing are latent. If we constantly explore what happens in our contexts, we will probably know more about our relationship with English and English language education. If we study the idea of exploring what we know and how we learned it, more chances to discover the foundations of our own local and situated scholarship and conditions can occur.

All these steps can lead us to discover more and more that we need to dismantle the idea that the grand narratives of ELT education are the only ones that tell the truth or the totality of what to do in ELT. Our scholarship will then gain extended validity among us and around the world.

Therefore, it is time to keep strengthening all local scholarship and all the possible academic connections with Colombian English-language teachers, educators, and researchers at all levels (school, university, language institutions). In this way, the construction of their teaching and research methodologies, practices, and knowledges can go together with, and furnish, the corresponding knowledge locally produced. As a community, we need to reclaim the local knowledge that foreign experts and publishing houses seem to have beclouded by establishing their discourses, conceptualizations, ideologies, and experiences.

The potency of the Colombian ELT scholarship is then evident in its publications and in the diversity of the topics of interest of its community, as well as in the actions to teach English in the Colombian multiplicity of contexts and the situated practices to educate new teachers of this language all around the country. As a community, we should keep all this scholarship going and spreading. 
However, it is also time to challenge the idea of the importation of ELT scholarship ${ }^{6}$ by considering local knowledges. As members of different strands of thought in the Colombian ELT community, we need to take ownership of our language teaching knowledge, practices, and experiences so that we can challenge the idea of adopting, adapting, or introducing foreign approaches for our contexts 7 . We need to divest ourselves of all that has colonized our ELT community so that we will be able to see what constructs our scholarship in context (most of it already evident in the articles about Colombian ELT by local authors). It is the development of self-belief that will allow us to grow as a community. We can then claim the right of having a well-recognized Colombian ELT all around the world ${ }^{8}$.

There is also a need to acknowledge that locally-produced knowledge has impacted practices. Mainly, student-teachers, teacher-researchers, and teacher educators are in a continuous attempt to develop reflections, materials, and ways to do things suited for specific observed needs that recognize the particularities of each context (e.g., Vásquez-Guarnizo et al., 2020; Quintero Polo, 2019; Cruz Arcila, 2018, to name only a few). Undoubtedly, more systematic context analysis and tailored proposals lead to renewed ELT teaching and learning practices.

\section{Concluding Remarks}

In tune with Global South principles and experience, we should not think of knowledge as being impartial, impersonal, universal, or delocalized. On the contrary, we English language teachers, educators, and researchers should praise and document the epistemological diversity of our realities. Little by little we have been learning to topple the statue of a single knowledge hierarchy that forefronts the foreign as the epitome of good theory and practice. As mentioned before, let us continue denaturalizing the grand narratives of the ELT field. Let us continue thinking-feeling, researching, and writing of literacies, interculturality, language assessment, professional development, pedagogical practicum, gender, bilingual policy (and more) in ways that help us regain the right to speak our truths (Mignolo, 2000).

We are at a point in history that demands committed work towards a deeper understanding of social realities and communities, and each day we are developing more suited methodologies and local frameworks of reference from which to start further explorations. Our field cannot

Or marketization (Usma Wilches, 2009) and businessification (Gonzalez Moncada, 2009) of English, and English language teaching and professional development.

With respect to this idea, see for example, Guerrero Nieto and Quintero Polo (2009), Romero Pinto (2013), Hurie (2018), Guerrero (2018), and Le Gal (2018).

8 This idea can also build awareness of the white supremacy in Colombian ELT, due to the hegemony and normalization of its postulates (see Estacio Barrios, 2017; Bonilla-Medina, 2017; Branschat, 2019). 
be alien to such happenings. The more areas of interest that are explored and documented locally, the better prepared we will feel to cope with the challenges that teaching and learning pose in particular Colombian contexts of ELT.

\section{References}

Anzaldúa, G. (1987). Borderlands/La frontera. Aunt Lute Books.

Arias-Cepeda, C. (2020). Exploring the Grounds for the Study of the Identity of Indigenous English Language Teachers in Colombia. GIST - Education and Learning Research Journal, 20, 189-214. https://doi.org/10.26817/16925777.713

Bastidas, J. A. (2017). More than half a century teaching EFL in Colombian secondary schools: Tracing back our footprints to understand the present. HOW, 24(1), 10-26. https://doi. org/10.19183/how.24.1.348

Bonilla Medina, S. X. (2017). Racial identity in educational practices in the context of Colombia [Unpublished doctoral dissertation]. University of East London, United Kingdom.

Bonilla-Mora, M. I., \& López-Urbina, J. P. (2021). Local Epistemological Perceptions that Underlie EFL Literature and Teaching Practices in Colombia. HOW, 28(2), 11-31. https://doi. org/10.19183/how.28.2.598

Branschat, F. (2019). Maximizing Colombia's Linguistic Capital with the Knowledge of Linguistic Imperialism and Linguistic Human Rights [Unpublished master's dissertation]. Universidad Icesi, Cali, Colombia.

Cárdenas, M. L. (2016). Challenges of the HOW journal in spreading teachers' works in times of ranking pressures. HOW, 23(2), 35-57. http://dx.doi.org/10.19183/how.23.2.333

Castañeda-Londoño, A. (2018). Towards the exploration of English language in-service teachers' ecologies of knowledges. In H. Castañeda-Peña et al., ELT local research agendas I (pp. 135160). Editorial Universidad Distrital Francisco José de Caldas.

Castañeda-Londoño, A. (2021). Moving from What Do English Teachers know? to How Do English Teachers Experience Knowledge? A Decolonial Perspective in the Study of English Teachers' Knowledge. GIST - Education and Learning Research Journal, 22, 75-101. https:/ / doi. org/10.26817/16925777.1002

Castañeda-Peña, H. (2018). Structuralist, postructuralist and decolonial identity research in English language teaching and learning: A reflection problematizing the field. In H. CastañedaPeña et al., ELT local research agendas I (pp. 17-34). Editorial Universidad Distrital Francisco José de Caldas.

Cruz Arcila, F. (2018). The wisdom of teachers' personal theories: Creative ELT practices from Colombian rural schools. Profile: Issues in Teachers' Professional Development, 20(2), 65-78.

Estacio Barrios, A. M. (2017). A Decolonial Perspective of the Native and Non-native Dichotomy in English Textbooks [Unpublished master's dissertation]. Universidad Distrital Francisco José de Caldas, Bogota, Colombia. 
Edgar Lucero

Adriana Castañeda-Londoño

Fals Borda, O. (1925-2008). Una sociología sentipensante para América Latina. Victor Manuel Moncayo Compilador. Siglo del Hombre Editores y CLACSO, (2009).

González Moncada, A. (2009). On Alternative and Additional Certifications in English Language Teaching: The Case of Colombian EFL Teachers' Professional Development. Íkala, 14(2), 183-209.

Granados-Beltrán, C. (2018). Revisiting the Need for Critical Research in Undergraduate Colombian English Language Teaching. HOW, 25(1), 174-193. https://doi.org/10.19183/ how.25.1.355

Guerrero Nieto, C. H., \& Quintero Polo, Á. H. (2009). English as a Neutral Language in the Colombian National Standards: A Constituent of Dominance in English Language Education. Profile: Issues in Teachers' Professional Development, 11(2), 135-150.

Guerrero, C. H. (2018). Problematizing ELT education in Colombia: Contradictions and possibilities, globalization and the emergence of emancipatory discourses. In H. Castañeda-Peña et al., ELT local research agendas I (pp. 121-132). Editorial Universidad Distrital Francisco José de Caldas.

Hurie, A. H. (2018). English for Peace? Coloniality, Neoliberal ideology, and Discursive Expansion in Colombia Bilingüe. Íkala, 23(2), 333-354. https://doi.org/10.17533/udea.ikala.v23n02a09

Le Gal, D. (2018). ELT in Colombia: A necessary paradigm shift. Matices, O(12), https://doi. org/10.15446/male.n12.73267

Lucero, E., \& Díaz, Z. (2016). Characterizing ASOCOPI: Its affiliates, ideals, and contributions. HOW, 23(2), 10-34. https://doi.org/10.19183/how.23.2.266

Martínez Boom, A. (2004). Hacia un atlas de la pedagogía en Colombia. Revista Alternativas, 35-36, 171-184.

Meadows, B. (2016). Culture teaching in historical review: On the occasion of ASOCOPI's fiftieth anniversary. HOW, 23(2), 148-169. https://doi.org/10.19183/how.23.2.294

Mejía Jiménez, M. R. (2011). Educaciones y pedagogías críticas desde el sur. Cartografía de la Educación popular. Editorial Quimantú.

Mignolo, W. (2000). Local histories/global designs: Essays on the coloniality of power, subaltern knowledges and border thinking. Princeton: Princeton University Press.

Mignolo, W. (2013). Geopolítica de la sensibilidad y del conocimiento. Sobre (de) colonialidad, pensamiento fronterizo y desobediencia epistémica. Revista de Filosofía, 74, 7-23.

Mignolo, W. D., \& Walsh, C. (2018). On decoloniality: Concepts, analytics, praxis. Duke University Press.

Moncada Linares, S. (2016). Othering: Towards a Critical Cultural Awareness in the Language Classroom. HOW, 23(1), 129-146. https://doi.org/10.19183/how.23.1.157

Núñez-Pardo, A. (2020). Inquiring into the Coloniality of Knowledge, Power, and Being in EFL Textbooks. HOW, 27(2), 113-133. https://doi.org/10.19183/how.27.2.566

Qin, Y. (2018). A multiverse of knowledge: Cultures and IR theories. The Chinese Journal of International Politics, 11(4), 415-434. https://doi.org/10.1093/cjip/poy015 
Quintero Polo, A. H. (2019). From utopia to reality: Trans-formation of pedagogical knowledge in English language teacher education. Profile: Issues in Teachers' Professional Development, 21(1), $27-42$.

Romero Pinto, M. A. (2013). The Effects of Linguistic Imperialism in the EFL Classroom. Enletawa Journal, (3 Jan). https://doi.org/10.19053/2011835X.1945

Saavedra, C. M., \& Pérez, M. S. (2018). Global south approaches to bilingual and early childhood teacher education: Disrupting global north neoliberalism. Policy Futures in Education, 16(6), 749-763. https://doi.org/10.1177/1478210317751271

Schmitz, J. R. (2017). English as a Lingua Franca: Applied Linguistics, Marxism, and Post-Marxist theory. Revista Brasileira de Lingüistica Aplicada, 17(2), 335-354.

Soto-Molina, J. E., \& Méndez, P. (2020). Linguistic Colonialism in the English Language Textbooks of Multinational Publishing Houses. HOW, 27(1), 11-28. https://doi.org/10.19183/ how.27.1.521

Ubaque-Casallas, D. F. (2021). Language Pedagogy and Identity. Learning from Teachers' Narratives in the Colombian ELT. HOW, 28(2), 33-52. https://doi.org/10.19183/how.28.2.604

Usma Wilches, J. A. (2009). Education and Language Policy in Colombia: Exploring Processes of Inclusion, Exclusion, and Stratification in Times of Global Reform. Profile: Issues in Teachers' Professional Development, 11(1), 123-141.

Vásquez-Guarnizo, J., Chía-Ríos, M., \& Tobar-Gómez, M. F. (2020). EFL Students’ perceptions on Gender Stereotypes through their Narratives. GIST - Education and Learning Research Journal, 21, 141-166. https://doi.org/10.26817/16925777.836 